\title{
A marine bacterial adhesion microplate test using the DAPI fluorescent dye: a new method to screen antifouling agents
}

\author{
C. Leroy ${ }^{a, b}$, C. Delbarre-Ladrat ${ }^{a}$, F. Ghillebaert ${ }^{b}$, M.J. Rochet $^{c}$, C. Compère ${ }^{d,{ }^{*}}$, D. Combes $^{e}$
}

aLaboratoire de Biotechnologie et Molécules Marines, IFREMER Nantes, France,

${ }^{\mathrm{b}}$ Mexel S.A. Verberie, France,

'Ecologie et Modèles pour l'Halieutique, IFREMER Nantes, France,

${ }^{\mathrm{d}}$ Service Interfaces et Capteurs, IFREMER Brest, France

é Laboratoire Biotechnologie-Bioprocédés, INSA Toulouse, France.

\begin{abstract}
*: Corresponding author : Ifremer, Service Interfaces et Capteurs, B.P. 70, 29280, Plouzané, France.
Tel.: +33 (0)2 982241 74; fax: +33 (0)2 982245 35; chantal.compere@ifremer.fr
\end{abstract}

\begin{abstract}
Aims: To develop a method to screen antifouling agents against marine bacterial adhesion as a sensitive, rapid, quantitative microplate fluorescent test.

Methods and Results: Our experimental method is based on a natural biofilm formed by monoincubation of the marine bacterium Pseudoalteromonas $s p$. D41 in sterile natural sea water in a 96 wells polystyrene microplate. The 4'6-diamidino-2-phenylindole (DAPI) dye was used to quantify adhered bacteria in each well. Total measured fluorescence in wells was correlated with the amount of bacteria showing a detection limit of one bacterium per $5 \mu \mathrm{m}^{2}$ and quantifying $2 \times 10^{7}$ to $2 \times 10^{8}$ bacteria adhered per $\mathrm{cm}^{2}$. The antifouling properties of three commercial surface active agents and chlorine were tested by this method in prevention of adhesion and also in detachment of already adhered bacteria. The marine bacterial adhesion inhibition rate depending on agent concentration showed a sigmoid shape like dose-response curve.
\end{abstract}

Conclusions: This test is well adapted for a rapid and quantitative first screening of antifouling agents directly in seawater in the early steps of marine biofilm formation.

Significance and impact of the study: In contrast with usual screenings of antifouling products which detect a bactericidal activity, this test is more appropriate to screen antifouling agents for bacterial adhesion removal or bacterial adhesion inhibition activities. This screening test focuses on antifouling properties of products, especially the first steps of marine biofilm formation.

Keywords: marine biofilm, DAPI, adhesion, microtiter plate, screening, Pseudoalteromonas, antifouling. 


\section{INTRODUCTION}

Any surface immersed in seawater is rapidly colonized by marine microorganisms and macroorganisms. Marine biofouling occurs on all underwater structures like vessels, cooling water systems, sensors, oil rigs and pipelines. Consequently, industrial performances are decreased and corrosion damage is generated (Flemming 2002). At the beginning of adhesion, bacteria colonize the surface and build up a biofilm (Kirchman and Mitchell 1981). Biofilm formation is usually described as four main successive steps: bacterial reversible adsorption, irreversible attachment, growth and partial detachment (Characklis, 1990).

To control micro and macro fouling in seawater systems, different techniques could be used: mechanical cleaning, treatment of the circulating water with biocides (e.g. chlorine, ozone, surfactant) or treatment of the walls in contact with sea water (e.g. antifouling paints with organometallic compounds or synthetic biocides) (Yebra et al. 2004). The legislation on biocides is becoming more and more restrictive, thus, the development of new environmental friendly antifouling agents is essential.

To minimise this initial adhesion and to screen antifouling agents in this context, new methods are required. Enumeration of bacteria in biofilm is usually performed by microscopy counting after cell labelling or by spreading cells on agar (Christensen et al. 2000). These techniques are tedious, slow and not adapted for a screening strategy; moreover, bacterial adhesion can be very heterogeneous making microscopy counting impossible.

O'Toole and Kolter (O'Toole et al. 1999) developed a microplate method to screen deficient mutants unable to grow as a biofilm, where bacteria were incubated in media supporting growth. Biomass attached on microtiter wells were stained with crystal violet and quantified by spectrophotometric measurement. Recently, this test has been performed to evaluate detergent or disinfecting agents against biofilm of pathogenic bacteria strains in growth media (Pitts et al. 2003; Augustin and Ali-Vehmas 2004; Kaplan et al. 2004; Henoun Loukili et al. 2004). It was also adapted using different stain such as CTC (5-Cyano-2,3-ditolyl tetrazolium chloride) (Pitts et al. 2003), calcofluor (Stagoj 2004), fluorogenic substrates (Augustin and Ali-Vehmas 2004), or radioactive labelling and GFP (Green Fluorescent Protein) tagged variants (Vesterlund et al. 2005).

The method developed in this article allows the screening of antifouling agents active on the irreversible attachment step of marine biofilm formation. It is a new, rapid and quantitative method which permits direct quantification of adhered marine bacteria in a microtiter plate in sea water. This test used a pioneer marine bacterial strain, isolated from a natural 24 hours marine biofilm, selected for its high adhesion capacity on different surfaces and its ability to produce extracellular polymeric substances (Pradier et al. 2005), and the DAPI fluorescent dye to stain adhered bacteria. Measurements of DAPI fluorescence have been correlated with microscopy counting; the efficiency of chlorine and three industrial products, usually used in cooling water systems to eliminate biofilm, has also been tested.

\section{MATERIALS AND METHODS}

\section{Biofilm forming bacterium}

D41 strain has been isolated from a natural marine biofilm on Teflon 24 hours immersed coupons in the Brest bay (France). For long-term storage, pure culture was maintained on Difco Marine Broth (MB) 2216E (Fischer Scientific Labosi, Elancourt, France) with $15 \%(\mathrm{v} / \mathrm{v})$ glycerol at $-80^{\circ} \mathrm{C}$. Analysis of 16sRNA sequence showed that D41 isolate is a member of the genus Pseudoalteromonas sp. (unpublished results).

\section{Bacterial adhesion in microplate}

Pseudoalteromonas sp. D41 was grown overnight on Difco Marine Agar (MA) 2216E (Fischer Scientific Labosi, Elancourt, France) at $25^{\circ} \mathrm{C}$, over which growth was removed and cells suspended in $10 \mathrm{ml}$ of natural sea water sterilized by filtration to $0.22 \mu \mathrm{m}$, to reach an O.D. of 2 at $600 \mathrm{~nm}$; the composition of the bacterial solution was $2 \times 10^{9} \mathrm{cfu} \mathrm{m}^{-1}$. $200 \mu \mathrm{l}$ of sterile sea water was inoculated on microplate first row wells and $200 \mu \mathrm{l}$ of bacterial suspension were inoculated on others wells using a 8channel pipette in a sterile black polystyrene NUNC microtiter plate with flat bottom (Bioblock, Illkirch, France). The covered microplate, containing 84 wells inoculated with bacteria, was incubated for 45 minutes, $1.5,3,5,10$ and 24 hours at $20^{\circ} \mathrm{C}$ with horizontal shaking (250 rpm).

Non adhered bacteria were eliminated by three successive hand washings: the microplate was manually reversed, $200 \mu \mathrm{l}$ of $36 \mathrm{~g} \mathrm{l}^{-1}$ sterile $\mathrm{NaCl}$ water solution was added and the microplate was shaken. Adhered bacteria were fixed for $1 \mathrm{~h} 30$ at $4^{\circ} \mathrm{C}$ with $200 \mu \mathrm{l}$ of $36 \mathrm{~g} \mathrm{I}^{-1}$ sterile $\mathrm{NaCl}$ water solution 
containing $2.5 \%$ formaldehyde, then stained for 20 minutes by adding $200 \mu \mathrm{l}$ of $4 \mu \mathrm{g} \mathrm{ml}^{-1}$ DAPI (Sigma-Aldrich, Saint Quentin, France). The excess stain was removed by three hand washings with $36 \mathrm{~g} \mathrm{I}^{-1} \mathrm{NaCl}$ water solution. The DAPI, complexed with bacterial DNA, was then solubilized in $200 \mu \mathrm{l}$ $95 \%$ ethanol for 15 minutes under gentle shaking. Fluorescence was measured at $350 \mathrm{~nm}$ excitation and $510 \mathrm{~nm}$ emission wavelengths using a Genios Plus microplate fluorescence reader (TECAN, Lyon, France).

All the chemicals and reagents were of analytical grade from Sigma-Aldrich.

Fluorescence measurements, bacteria counting and method limit.

D41 isolate was grown overnight on $\mathrm{MA}$ at $25^{\circ} \mathrm{C}$, scraped and suspended in $36 \mathrm{gl}^{-1}$ sterile $\mathrm{NaCl}$, water solution containing $2.5 \%$ formaldehyde. Dilutions were performed to reach an O.D. at $600 \mathrm{~nm}$ between 0.05 and $0.5 \mathrm{in} 4 \mathrm{ml}$ final volume. Bacteria were then stained with DAPI as described above. Three series of five dilutions were tested.

One part of the DAPI stained bacterial suspension was filtered onto a $0.22 \mu \mathrm{m}$ sterile black polycarbonate filter (45 mm diameter, Isopore GTBP Millipore, Fischer Scientific Labosi, France). The filters were rinsed with sterile water and mounted onto glass slides. The slides were observed under 1000 magnification on epifluorescence microscopy using an Olympus BH201 under WU filter. Approximately 1250 cells were counted per filter from 25 different fields.

For the other part of the DAPI stained bacterial suspension, excess stain was removed by three successive washings by centrifugation at $9500 \mathrm{~g}$ for $10 \mathrm{~min}$ in $36 \mathrm{~g} \mathrm{I}^{-1}$ sterile NaCl solution. After the last centrifugation, the pellet was suspended in $500 \mu \mathrm{l}$ ethanol. $200 \mu \mathrm{l}$ were transferred into a black microplate well and the fluorescence was measured as described above. The fluorescence measured per well is then reported according to the number of bacteria in suspension enumerated for the same sample volume.

The detection limit is determined as the ratio between the minimum number of bacteria detected per well and the area of the contact surface. Well with bacterial suspension contact surface is calculated by adding the bottom and the side surfaces of the well: $S=r^{2}+2 \quad r h ; h=v / \quad r^{2}$; ( $S$ is surface, $\mathrm{h}$ is height, $\mathrm{r}$ is radius, $\mathrm{v}$ is volume of bacterial suspension).

\section{Agents effectiveness}

Industrial cleaning agents P1, P2 and P3 (Mexel S.A., Verberie, France) are surface active agents, respectively an alkylamine product in solution, an alkylglucoside and an alkylamine product in aqueous emulsion. Chlorine was also used as a $10 \%$ sodium hypochlorite solution concentrated with a density at $1.206 \mathrm{~g} \mathrm{ml}^{-1}$ (Sigma-Aldrich, Saint Quentin, France).

The "prevention test" consisted of pouring $50 \mu \mathrm{l}$ of each product into each well one hour before adding $200 \mu \mathrm{l}$ of bacterial suspension as described above. The "detachment test" consisted of allowing D41 to adhere before adding each product. After bacterial adhesion during 3 hours and washing as described above, $50 \mu \mathrm{l}$ of each product were poured into each well and $200 \mu \mathrm{l}$ of sterile sea water were then added. Products were incubated for one hour while horizontally shaking at $20^{\circ} \mathrm{C}$. Three washings in $36 \mathrm{~g} \mathrm{I}^{-1} \mathrm{NaCl}$ water solution were performed before fixation and DAPI staining was performed as described above.

For each conditions, each product was tested twice on two different microplate, on two different day in a large range of concentration (from $10^{-2}$ up to $10^{5} \mathrm{mg}^{-1} \mathrm{I}^{-1}$ ) using serial two fold dilutions. Each concentration of product was deposited twice or three times on the same line per microplate.

The bacterial adhesion Percentage Reduction (PR) was calculated from fluorescence of the blank ( $F_{B}$; without bacteria), fluorescence of the control $\left(F_{C}\right.$; bacteria without product) and fluorescence of the sample $\left(F_{S}\right.$; with bacteria and agent tested) (Equation (1)).

$$
\mathrm{PR}=\left\{\left[\left(\mathrm{F}_{\mathrm{C}}-\mathrm{F}_{\mathrm{B}}\right)-\left(\mathrm{F}_{\mathrm{S}}-\mathrm{F}_{\mathrm{B}}\right)\right] /\left(\mathrm{F}_{\mathrm{C}}-\mathrm{F}_{\mathrm{B}}\right)\right\} \times 100
$$

IC50 values (product concentration necessary to reach half maximum inhibition) were calculated by using Sigmaplot 9.0 software (Systat Software Gmbh, Erkrath, Deutschland). Experimental results were fitted to a sigmoidal equation (four parameter logistic equation) by a non linear regression.

\section{Statistical analysis}

Analysis of variance was performed using Statgraphics Plus 5.1 software (Sigma Plus). The significant statistical level was set at $p<0.05$. Results shown are average values \pm standard deviation (SD). 


\section{RESULTS}

Fluorescence of ethanol solubilized DAPI was measured and correlated with the number of suspended bacteria stained with DAPI. An assumption was made that the same number of suspended bacteria and adhered bacteria was stained at the same level by DAPI. Figure 1 shows a good correlation between fluorescence measurement per well and bacteria counting by microscopy $\left(R^{2}=\right.$ 0.91). According to the contact surface between the well and the bacterial suspension $\left(1.8148 \mathrm{~cm}^{2}\right)$, the lower detection limit represents about $3.75 \times 10^{7}$ attached cells per well i.e. one bacterial cell per 5 $\mu \mathrm{m}^{2}$. Our method allow quantification of adhered marine bacteria in well from about $2 \times 10^{7}$ to $2 \times 10^{8}$ bacteria per $\mathrm{cm}^{2}$.

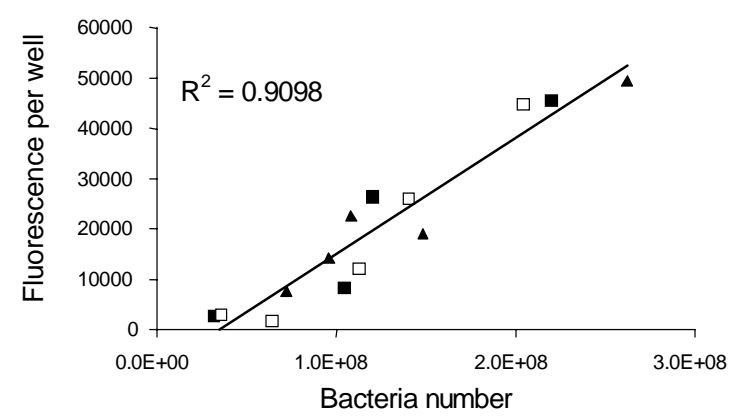

Fig. 1 Correlation between DAPI fluorescence in microtiter wells after DAPI solubilization in ethanol and DAPI bacteria enumerated by epifluorescence microscopy, from the same sample of suspended stained DAPI bacteria. Three series were done with five dilutions each.

Pseudoalteromonas sp. D41 on polystyrene surface adheres in an exponential way (Fig. 2). The number of bacteria bound to the polystyrene surface of the microplate increased very quickly at the beginning of the bacterial adhesion and more slowly after 3 hours incubation time. In view of these results, a 3 hours bacterial adhesion time was chosen to screen surface active agents and chlorine for their antifouling activity.

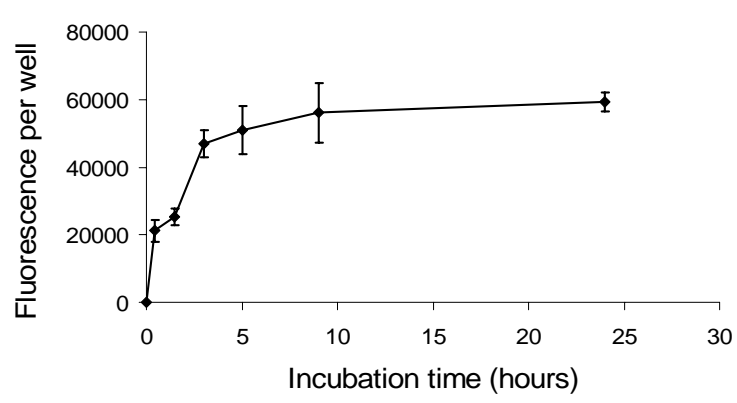

Fig. 2 Kinetics of bacterial adhesion followed by fluorescence of DAPI complexed by DNA. SD was calculated from 84 values, i.e. 84 wells of adhered bacteria in one microplate per incubation time.

Analysis of variance was made within control microplate at different times of bacterial adhesion with the first fixed factor as row, and second as column, using fluorescence intensity as the variable. The row position effect appeared to be not statistically significant (for $0.5,1,3,4,6,16$ and 24 hours of D41 incubation times, $p$ is respectively $0.5,0.96,0.74,0.93,0.09,0.5$ and 0.52 ) in contrast with the column position effect ( $p=0$ for every D41 incubation time). A multiple means comparison showed no particular column responsible for this observation but a global spatial column effect. 
Therefore a blank, without antifouling product and without bacteria, as well as a control, without product but with bacteria, were included in each column of the experimental microplate to test industrial products efficiency. In order to detect the column position effect on the percentage reduction rate by variance analysis, the efficiency of industrial products was tested twice, and three times in the same line per microplate but in different columns. The column position effect was not statistically significant on the percentage reduction rate.

The curves corresponding to bacterial adhesion reduction percentage according to the product concentration have a sigmoid shape when a logarithmic scale is applied onto concentrations, characteristic of dose-response curves (Fig. 3). The product has no effect under a minimal concentration, then the response increases to reach a maximum effect or "plateau". Only P1 in bacterial detachment did not show a "plateau" at highest concentration but seemed to exhibit an optimal concentration for cleaning efficiency. Moreover, all the values obtained were able to be fitted with a four-parameter logistic equation with software SigmaPlot 9.0 enabling derivation of statistically significant IC50 values (Table 1). IC50 values enabled comparison of products effectiveness. Alkylamines P1 and P3 were 23 to 35 times better on bacterial adhesion prevention and up to 40 times in bacterial detachment than alkylglucoside P2. These differences between P1 and P2 and between P3 and P2 are stastistically significant at 95\% $(p<0.0001)$ for both protocoles (A and B) For $\mathrm{P} 1$ and $\mathrm{P} 3, \mathrm{IC} 50$ indicate a statistically stronger effect on detachment than prevention at respectively $95 \%(p=0.026)$ and $75 \%(p=0.252)$. The maximum inhibition rate was about $99 \%$ for $\mathrm{P} 1$ in prevention at about $500 \mathrm{mg} \mathrm{l}^{-1}$. Chlorine is the most effective agent in bacterial adhesion prevention with an IC50 at about $12 \mathrm{mg} \mathrm{l}^{-1}$ and a $99 \%$ reduction rate reached at $78 \mathrm{mg} \mathrm{l}^{-1}$. Surprisingly, negative values could also be observed especially for $\mathrm{P} 3$ in detachment at concentrations lower than $100 \mathrm{mg} \mathrm{ml}^{-1}$ showing an increase of bacterial adhesion.

Table 1 : IC50 values in $\mathrm{mg} \mathrm{I}^{-1}$ calculated from experimental values fitted to a four-parameter logistic equation $(p<0.05)$.

\begin{tabular}{lll}
\hline & Adhesion prevention & Detachment \\
\hline P1 & $67 \pm 5$ & $46 \pm 5$ \\
P2 & $2384 \pm 256$ & $1741 \pm 184$ \\
P3 & $104 \pm 6$ & $75 \pm 11$ \\
$\mathrm{HClO}$ & $12 \pm 1$ & $207 \pm 32$ \\
\hline
\end{tabular}


A
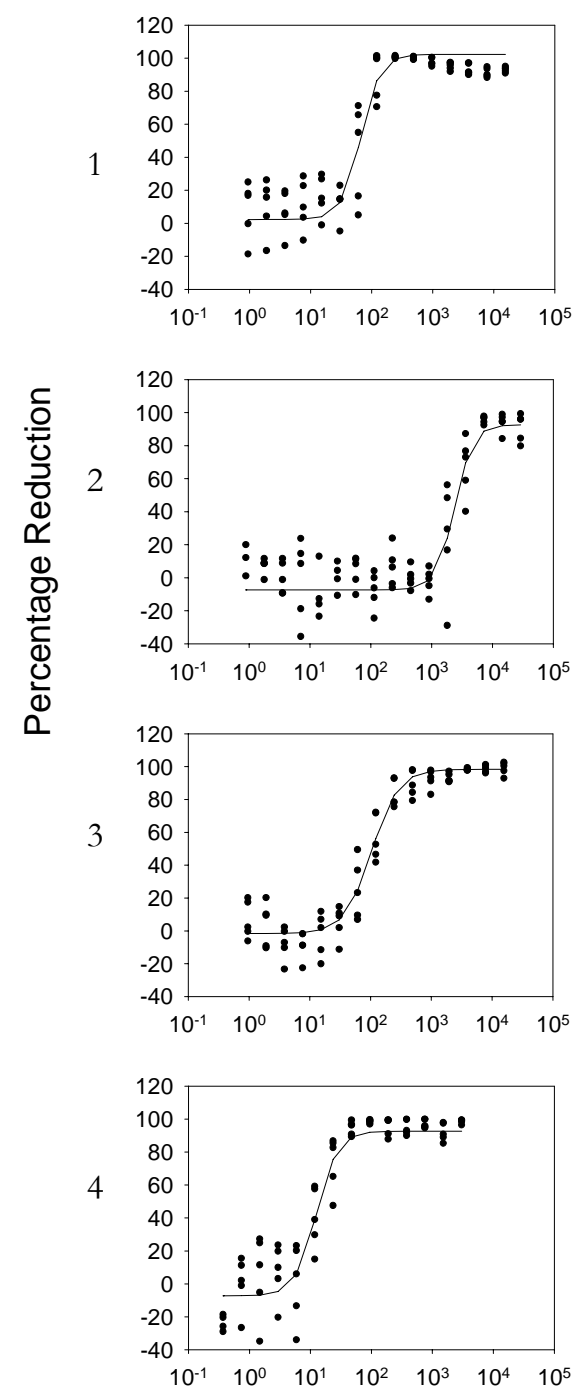

B
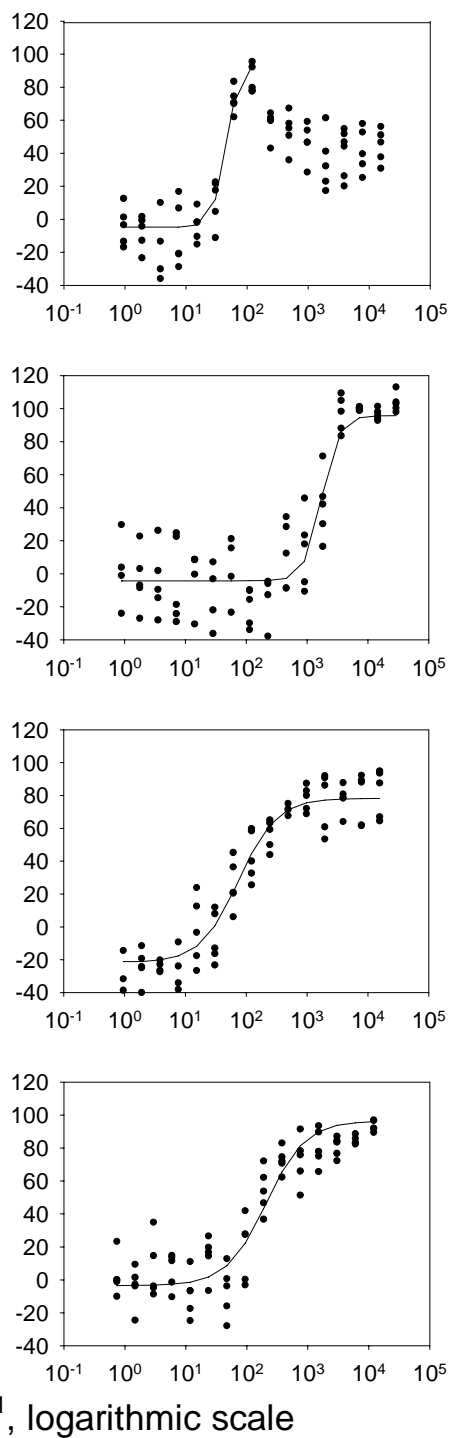

Fig. 3 Reduction percentage of bacterial adhesion in microtiter plate according to industrial agent concentration in $\mathrm{mg} \mathrm{I}^{-1}$ for P1 (line 1), P2 (line 2), P3 (line 3) and HClO (line 4). Products were tested in prevention of adhesion column A (agent is adding before bacteria and then incubated 3 hours) and in detachment column B (washing during one hour of already 3 hours adhering bacteria). Curves represent fitting of all experimental values depending on the four-parameter logistic equation. 


\section{DISCUSSION}

Studies to characterize and screen potential antifouling properties of natural extracts have been previously reported, especially for macroalgae or microbial extracts (Hellio et al. 2001; Holmström et al. 2002; Marechal et al. 2004). Assays developed in these works are similar to antibiotic tests (Amsterdam, 1996) with the antifouling activity assigned as a minimum concentration for inhibiting bacteria growth (MIC). However, killing adhered microorganisms does not mean removal it from the surface. The test we developed in this study is appropriate to screen potential antifouling properties by detecting removal activity. Moreover, the quantification of adhered bacteria does not need the removal of bacteria by scrapping or sonicating, like in Calgary device (Ceri et al 1999).

In this assay, we incubated Pseudoalteromonas sp. D41 directly in sea water, in stationary growth phase and at a high density level $\left(2 \times 10^{9} \mathrm{cfu} \mathrm{m}^{-1}\right)$. D41 was not in a medium supporting growth and did not grow in sea water within 24 hours (data not shown). To quantify bacterial adhesion in each well, fluorescence measurement per well was correlated with fluorescence microscopic enumeration of the same sample when cells are stained in suspension. Our method detects marine bacterial adhesion from about $3.75 \times 10^{7}$ to $3.75 \times 10^{8}$ bacteria per well which represents $10 \%$ to $90 \%$ of the colony forming units deposited at the beginning. This could explain the plateau of the adhesion curve shape related to the decrease of suspended bacteria. The lower detection limit represents about $3.75 \times 10^{7}$ attached cells per well i.e. one bacterial cell per $5 \mu^{2}$. The limit of detection of adhered bacteria in microtiter wells, whatever the stain, is difficult to find in literature. Kolter and O'Toole talked of about 1 cell per $\mu^{2}$ for the crystal violet microplate method (O'Toole et al. 1999) and Christensen et al. confirmed that this method will not detect low levels of surface colonization (Christensen et al. 2000).

The column position effect is significant on the bacterial adhesion. Actually, bacteria in suspension are deposited into microplate per column with a 8-channel pipette, with one column filled at a time. This could explain the observed variability between columns. So the method could be improved by controlling the way to lay down the bacterial suspension into the microplate wells. Using a positive and a negative control inside each column of the microplate to calculate the inhibition rate shows that the column position effect was not statistically significant onto the percentage reduction rate. Moreover, testing a large range of product concentration with a serial two fold dilutions lead data able to be fitted with a four-parameter logistic equation with statistically significant parameters, like IC50.

Industrial agents were tested using our method. We could observe different IC50 values depending on the protocol selected : "detachment test" or "prevention test". Results of tested products can be related to their industrial application. Chlorine is the most effective agent in prevention test, and its effectiveness is better in prevention than in detachment test, related to its disinfectant and bactericidal properties in solution. P1 and P3 show an IC50 better in detachment than in prevention, related to there surface active agent properties. There effectiveness in the prevention test could also be attributed in part by an alteration of the surface properties. Considering all the data, P2 is the least effective agent. That was expected because $\mathrm{P} 2$ is used industrially to remove fat from surfaces and not attached bacteria. This shape of the P1 detachment curve is very different from the others, since after a maximum concentration, the inhibition rate decreases, assays are currently in progress to better understand this behaviour. P3 shows negative values corresponding to an increase of bacterial adhesion. This phenomenon has already been observed in presence of antimicrobial agents (Mah and O'Toole, 2001; Stewart and Costerton, 2001) or when insufficient amount of biocide was applied (Grant and Bott, 2005). Different hypothesis could explain these observations such as multiple resistance mechanisms leading to persistence of biofilm community.

Actually effective product concentrations test are higher compared to concentrations used in industrial systems. P1, P3 and chlorine are used in water cooling systems from 5 to $10 \mathrm{mg} \mathrm{I}^{-1}$ and our assay shows an IC50 respectively at 46, 75 and $12 \mathrm{mg} \mathrm{l}^{-1}$. This difference could be explained in part by the high number of adhered cells in the well. But the method could also be improved (i) by changing the agent exposure time and/or (ii) by renewing the active agent. Moreover, our results with chlorine and D41 detachment are coherent with those obtained by the crystal violet test onto Staphylococcus aureus adhesion (Pitts et al., 2003) showing that this method could be used against different bacterial strains involved in other domains (medical, dental, industrial food process...).

For a first screening of potential antifouling products, effective in marine conditions, this test is very well adapted: (i) it is rapid and reproducible for inhibition rate; (ii) it is developed using natural sea water and natural marine biofilm bacterium; (iii) it is focused on the first steps of bacterial adhesion; (iv) prevention and detachment effectiveness could be studied. 


\section{REFERENCES}

Amsterdam, D. (1996) Susceptibility testing of antimicrobials in liquid media. In Antibiotics in Laboratory Medicine (4th ed.) ed. Lorian, V. pp.52-111. Williams and Wilkins, Baltimore, MD.

Augustin, M. and Ali-Vehmas, T. (2004) Assessment of enzymatic cleaning agents and disinfectants against bacterial biofilms. J Pharm Pharmaceut Sci 7, 55-64.

Ceri, H., Olson, M.E., Stremick, C., Read, R.R., Morck, D., Buret, A. (1999) The Calgary biofilm device: new technology for rapid determination of antibiotic susceptibilities of bacterial biofilms. $J$ Clin Microbiol 37, 1771-1776.

Characklis W.G. (1990) Microbial fouling. In Biofilms ed. Characklis, W.G., Marshall, K.C. pp.523-584. Wiley, New York.

Christensen, G.D., Simpson, W.A., Anglen, J.O., Gainor, B.J. (2000) Methods for evaluating attached bacteria and biofilms. In Handbook of bacterial adhesion: principles, methods and applications ed. An, Y.H., Friedman, R.J. pp.213-233. Humana Press Inc., Totowa. NJ.

Flemming, H.C. (2002) Biofouling in water systems - cases, causes and countermeasures. Appl Microbiol Biotechnol 59, 629-640.

Grant, D.M. and Bott, T.R. (2005) Biocide dosing strategies for biofilm control. Heat Trans Eng 26, 4450.

Hellio, C., De La Broise, D., Dufossé, L., Le Gal, Y., Bourgougnon, N. (2001) Inhibition of marine bacteria by extracts of macroalgae : potential use for environmentally friendly antifouling paints. Mar Environ Research 52, 231-247.

Henoun Loukili, N.H., Zink, E., Grandadam, S., Bientz, M., Meunier, O. (2004) Effectiveness of detergent-disinfecting agents on Escherichia coli 54127 biofilm. J Hosp Infect 57, 175-178.

Holmström, C., Egan, S., Francks, A., McCloy, S., Kjelleberg, S. (2002) Antifouling activities expressed by marine surface associated Pseudoalteromonas species. FEMS Microbiol Ecol 41, 4758.

Kaplan, J.B., Ragunath, C., Velliyagounder, K., Fine, D.H., Ramasubbu, N. (2004) Enzymatic detachment of Staphylococcus epidermis biofilms. Antimicrob Agents Chemother 48, 2633-2636.

Kirchman, D. and Mitchell, R. (1981) A biochemical mechanism for marine biofouling. Oceans Sep, 537-541.

O'Toole, G.A., Pratt, L.A., Watnick, P.I., Newman, D.K., Weaver, V.B., Kolter, R. (1999) Genetic approaches to study of biofilms. Methods Enzymol 310, 91-109.

Mah, T.-F.C. and O'Toole, G.A. (2001) Mechanisms of biofilm resitance to antimicrobial agents. Trends Microbiol 9, 34-39.

Maréchal, J.P., Culioli, G., Hellio, C., Thomas-Guyon, H., Callow, M.E., Clare, A.S., Ortalo-Magné, A. (2004) Seasonal variation in antifouling activity of crude extracts of the brown alga Bifurcaria bifurcata (Cystoseiraceae) against cyprids of Balanus amphitrite and the marine bacteria Cobetia marina and Pseudoalteromonas haloplanktis. J Exp Mar Biol Ecol 313, 47-62.

Pitts, B., Hamilton, M.A., Zelver, N., Stewart, P.S. (2003) A microtiter-plate screening method for biofilm disinfection and removal. $J$ Microbiol Methods 54, 269-276.

Pradier, C.M., Rubio, C., Poleunis, C., Bertrand, P., Marcus, P., Compère, C. (2005) Surface characterisation of three marine bacterial strains by FTIR, XPS, and ToF-SIMS, correlation with adhesion on stainless steel surfaces. J Phys Chem 109, 9540-9549.

Stagoj, M.N., Komel, R., Comino, A. (2004) Microtiter plate assay of yeast cell number using the fluorescent dye Calcofluor White M2R. BioTechniques 36, 380-382.

Stewart, P.S. and Costerton, J.W. (2001) Antibiotic resistance of bacteria in biofilms. Lancet 358, 135138.

Vesterlund, S., Paltta, J., Karp, M., Ouwehand, A.C. (2005) Measurement of bacterial adhesion--in vitro evaluation of different methods. J Microbiol Methods 60, 225-33.

Yebra, D.M., Kiil, S., Dam-Johansen K. (2004) Antifouling technology-past, present and future steps towards efficient and environmentally friendly antifouling coatings. Prog Org Coat 50, 75-104. 